\title{
LIVEWEIGHT GAINS BY SHEEP GRAZING BROWNTOP AND PERENNIAL RYEGRASS
}

\author{
J. A. Lancashire \\ Grasslands Division, DSIR, Palmerston North
}

M. J. Ulyatt

Applied Biochemistry Division, DSIR, Palmerston North

\section{A bstract}

The liveweight gain of young sheep set-stocked on browntop and 'Grasslands Ruanui' perennial ryegrass pastures was compared during the main periods of pasture growth over two years. During spring there was no difference between the two species, but in early summer, although flowering was suppressed by grazing, the higher liveweight gains on ryegrass were attributed to greater stem and stolon development and poorer leaf growth in the browntop pasture. In early autumn an outbreak of staggers in the ryegrass sheep apparently reduced liveweight gain relative to browntop where no staggers occurred. These differences are discussed in relation to the closer grazing of ryegrass than browntop at this time of year.

\section{INTRODUCTION}

EARLIER PAPERS in this session have shown that browntop (Agrostis tenuis Sibth) is extremely widespread in pastures and clearly must contribute substantially to the diet of the grazing animal in New Zealand. Although little information is available on the feeding value of browntop, it is generally regarded as being reasonably nutritious if kept in a short, young stage of growth. However, it is believed that feeding value will be reduced very rapidly if it is allowed to become long and rank, particularly during the flowering period over summer (Levy, 1970). This observation was confirmed by Black (1967) in Scotland who showed that high digestibility figures for browntop in early spring could only be maintained later in the season if flowering was prevented.

Limited information is also available on the chemical composition of browntop. Suckling (1960) and Henderson et al. 
(1962) showed over a range of seasons and growth stages that the crude protein content of browntop was consistently higher than for a large number of other grasses including perennial ryegrass.. Brcvwntop had a generally low ranking compared with a range of legumes and other grasses including perennial ryegrass in a grazing preference trial (Cowlishaw and Alder, 1960). This was attributed to differences; in several parameters among which were a relatively high lignin content and a relatively low soluble carbohydrate content in browntop compared with the more preferred species.

In order to obtain more detailed information on the feeding value of browntop under grazing, a series of comparisons with perennial ryegrass were carried out at Palmerston North between 1971 and 1973 and some of the results obtained are presented here.

\section{EXPERIMENTAL}

The experimental area was located on Paddocks 16 and 17 of Massey University's No. 1 'sheep farm which is on a gleyed yellow-grey earth soil (Tokomaru silt loam). Twelve paddocks each of approximately 0.20 ha were autumn-ploughed and winterfallowed and then half were sown with the equivalent of $56 \mathrm{~kg} /$ ha of browntop and $34 \mathrm{~kg} / \mathrm{ha}$ of 'Grasslands Ruanui' perennial ryegrass (Lolium perenne L.) on a randomized block basis in October 1969. Super-phosphate and nitro-lime $(20.5 \% \mathrm{~N})$ were each applied at the rate of $251 \mathrm{~kg} / \mathrm{ha}$ at sowing. Subsequently $376 \mathrm{~kg}$ superphosphate/ha were applied each autumn, and 156 to $224 \mathrm{~kg} \mathrm{~N} /$ ha were applied each year in approximately equal amounts at 3-monthly intervals to maintain grass growth in the absence of a legume.

The paddocks were sprayed annually with 0.92 1/ha of picloram to produce pure grass swards free of weeds and white clover. During establishment, plots were rotationally grazed by sheep and although browntop was slow to develop into a dense sward all pastures were in a suitable condition for the experiment to start in spring 197 1. Standard evaluation trials (Rae et al., 1963) were carried out with hoggets set-stocked at 35/ha and 36 animals/treatment in spring-early summer 1971-2 and 1972-3 and 'autumn-early winter 1972 and 1973. The major criterion in this type of trial is that the growth rate of the animals is not limited by pasture availability and, if necessary, sheep are removed at random or extra sheep are bought in to control 
surplus pasture growth. These latter sheep are not included as experimental animals. Liveweights were obtained at 2- to 4weekly intervals and all sheep were routinely drenched with thiabendazole and treated with a vaccine to prevent foot-rot.

Herbage was sampled at intervals for chemical analysis (Bailey, 1967) and for in vitro organic matter digestibility (Terry and Tilley, 1964).

\section{RESULTS AND DISCUSSION}

As similar effeots were obtained in each year, detailed results are presented from only one trial in each season.

\section{SPRING-EARLY $\quad$ SUMMER $\quad 1972-3$}

Figure 1 shows the typical pattern at this period of the year with little difference in liveweight gain over the main spring

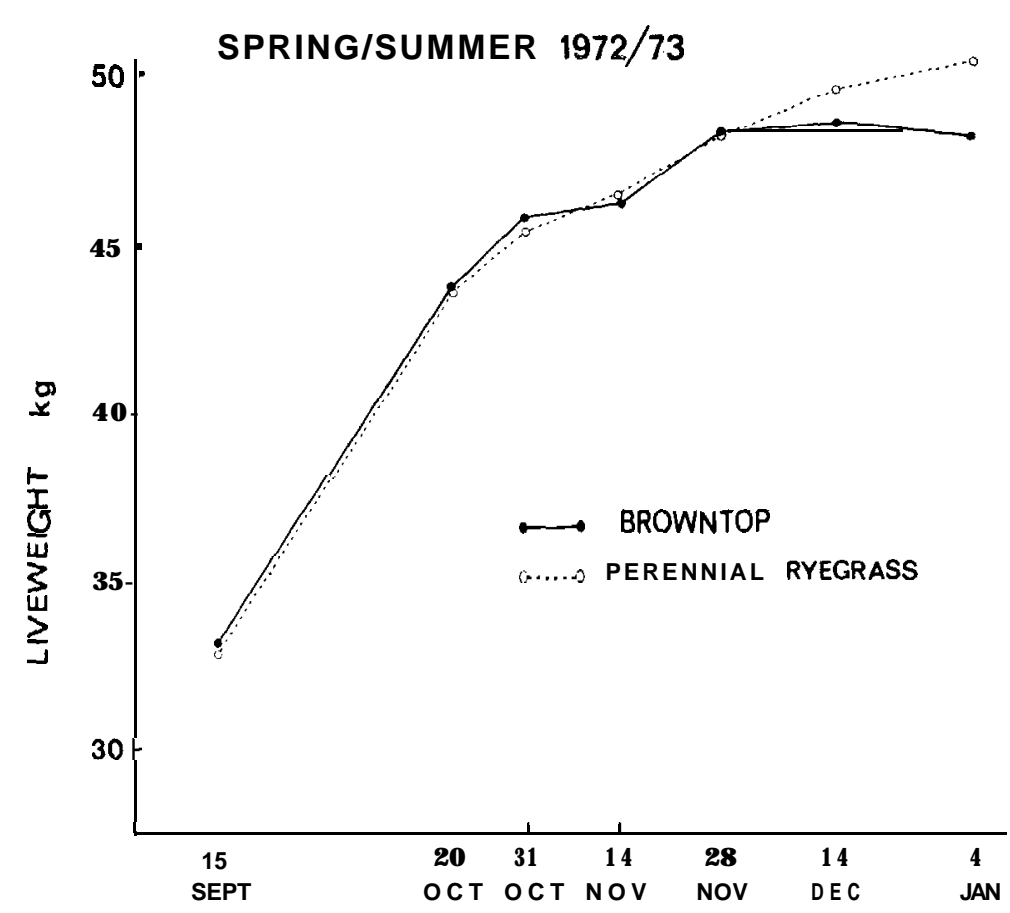

Fig. 1: Liveweight gain $(\mathrm{kg})$ of sheep, spring-summer, 1972-3. 
flush period, followed by a divergence in favour of ryegrass in early December. The extent of this difference is demonstrated in Table 1 which shows the liveweight change in the final stages of the experiment before shortage of feed became a limiting factor in early January. Table 2 shows similar results in 1971-2 where the experiment was carried on further until the animals

TABLE 1: MEAN LIVEWEIGHT CHANGE (kg/SHEEP) IN THE FINAL STAGES OF 1972-3 EXPERIMENT

(November 28, 1972 to January 4, 1973)

\begin{tabular}{llllll} 
Browntop & $\ldots$ & $\ldots$ & $\ldots$ & $\ldots$ & 0.12 \\
Perennial ryegrass & $\ldots$ & $\ldots$ & $\ldots \cdot$ & +3.62 \\
S.E. $\quad \ldots$ & $\ldots$ & $\ldots$ &. & $\ldots$ & $1.06\left({ }^{*}\right)$ \\
\hline
\end{tabular}

TABLE 2: MEAN LIVEWEIGHT (kg) OF SHEEP IN FINAL STAGES

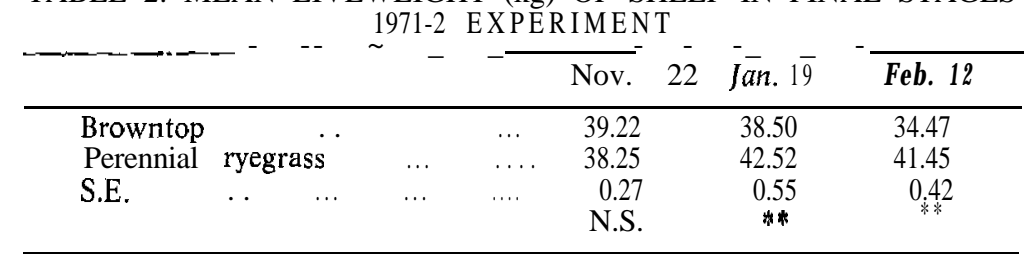

TABLE 3: CHEMICAL COMPOSITION OF PASTURES SPRING. EARLY SUMMER 1972-3 (\% DRY MATTER)

\begin{tabular}{|c|c|c|c|c|c|}
\hline \multirow[b]{2}{*}{ Oct. 16,1972} & \multicolumn{2}{|c|}{ Hemicellulose Cellulos } & \multicolumn{2}{|c|}{$\begin{array}{l}\text { Crude } \\
\text { Protein Lignin }\end{array}$} & \multirow[t]{2}{*}{$\begin{array}{c}\text { O.M. } \\
\text { Digestibility } \\
(\%)\end{array}$} \\
\hline & & & & & \\
\hline Browntop & 12.3 & 19.0 & 22.1 & 3.3 & 82.0 \\
\hline Ryegrass & 11.7 & 20.9 & 19.6 & 2.5 & 85.0 \\
\hline S.E. & 0.09 & 0.15 & 0.21 & 0.04 & \\
\hline Oct. 29, 1972: & & & & & \\
\hline Browntop & 14.0 & 20.0 & - & 2.9 & 81.8 \\
\hline Ryegrass & 13.7 & 20.8 & - & 2.5 & 86.5 \\
\hline $\begin{array}{l}\text { S.E. } \\
\text { Dec } 20 .\end{array}$ & 0.03 & 0.19 & & - & \\
\hline $\begin{array}{c}\text { Dec. 20, } 19 / 2: \\
\text { Browntop }\end{array}$ & 17.8 & 20.3 & 17.2 & 5.4 & 61.3 \\
\hline Ryegrass & 16,8 & 25.4 & 13.1 & 5.2 & 68.8 \\
\hline S.E. & 0.09 & 0.37 & 0.07 & 0.03 & \\
\hline Feb. 5, 1973: & & & & & \\
\hline Browntop & 20.3 & 20.7 & 12.4 & 7.0 & 49.0 \\
\hline Ryegrass & 17.8 & 26.3 & 10.9 & 6.4 & 60.5 \\
\hline S.E. & 0.02 & 0.27 & 0.21 & 0.02 & \\
\hline
\end{tabular}




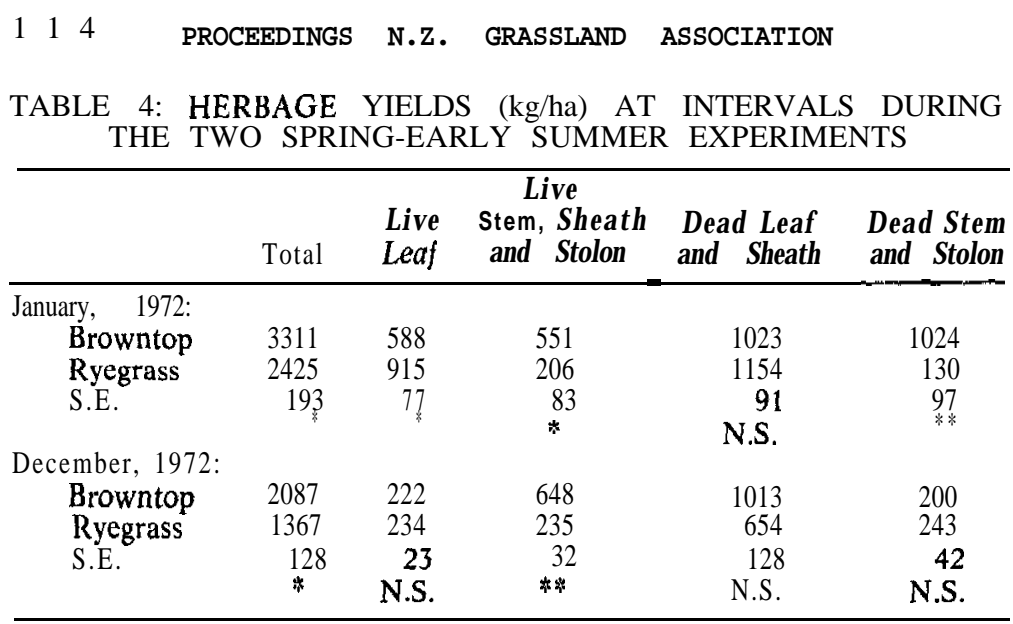

on the ryegrass treatment showed a slight weight loss in the final period.

Although the management procedures used in these experiments suppressed development of flower heads, Tables 3 and 4 show that there were marked changes in chemical and botanical composition of the pastures over the experimental period. In general, hemicellulose, lignin, and crude protein were higher in browntop and cellulose and in vitro O.M. digestibility were higher in ryegrass. The general increase in structural components over the period was associated with a gradual decline in digestibility which corresponded with the greater loss of weight of the sheep on browatop. The differences between the two grasses in botanical composition at this time of year are illustrated in Table 4. Although there were generally greater yields in the browntop pasture, most of the extra dry matter was generally made up of live or dead stem and stolon of poor feeding value, while the yield of live green leaf was generally smaller or at least no greater than that in the ryegrass pasture. These data support the statement that changes in digestibility are functions of changes in proportions of leaf, leaf sheath, and stem (Terry and Tilley, 1964), and, in the case of browntop, presumably also stolon.

\section{Autumn-Early Winter 1972}

Figure 2 shows a marked divergence in the initial stages of the experiment with loss of weight by the ryegrass sheep being followed by a gradual recovery later in the season so that there was no significant difference evident by the end of the experiment 
WEIGHT GAIN BY SHEEP

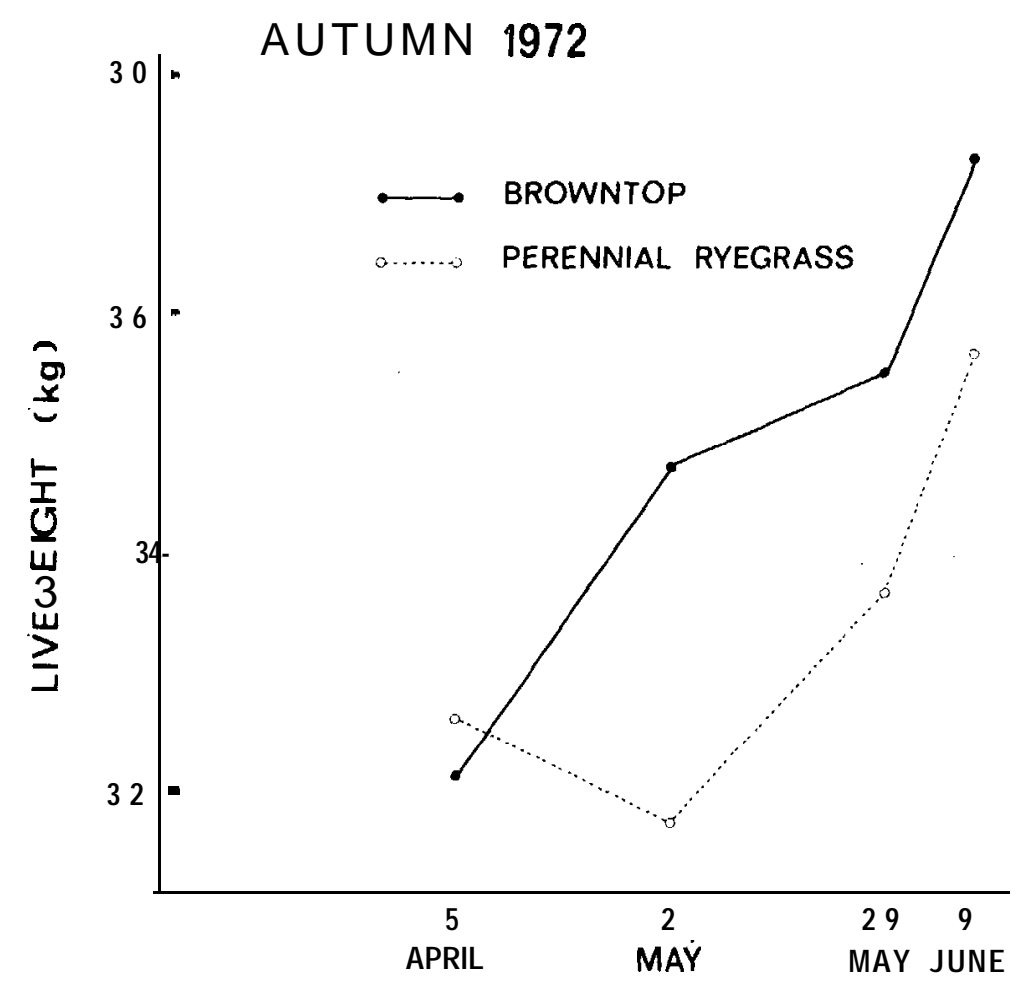

FIG. 2: Livew eight gain (kg) of sheep, autumn, 1972.

TABLE 5: MEAN LIVEWEIGHT CHANGE (kg/SHEEP) IN AUTUMN 1972 EXPERIMENT

\begin{tabular}{|c|c|c|c|c|c|}
\hline & & Apr. 5-May 2 May & 2-May 29 & M ay 29-Jun. 9 & Total \\
\hline $\begin{array}{l}\text { Browntop } \\
\text { Perennial } \\
\text { S.E. }\end{array}$ & ryegrass & $\begin{array}{r}+2.57 \\
-0.92 \\
0.38\end{array}$ & $\begin{array}{c}+0.83 \\
+1.93 \\
0.18 \\
+4\end{array}$ & $\begin{array}{c}+1.70 \\
+2.00 \\
0.51 \\
\text { N.S. }\end{array}$ & $\begin{array}{c}+5.10 \\
+3.01 \\
0.59 \\
\text { N.S. }\end{array}$ \\
\hline
\end{tabular}

-(Table 5). No particularly unusual chemical (Table 6) or botanical composition features were present during the experiment except that browntop was much leafier than earlier in the year and ryegrass tended to be higher in crude protein.

The main animal feature was the presence of severe staggers in the ryegrass sheep during April but none was observed in the 
TABLE 6: CHEMICAL COMPOSITION OF PASTURES IN AUTUMN 1972 (\% DRY MATTER)

\begin{tabular}{|c|c|c|c|c|}
\hline & Hemicellulose & Cel I ul ose & Protein & Lignin \\
\hline \multicolumn{5}{|l|}{ May 28, 1972: } \\
\hline Browntop & 13.8 & 15.9 & 18.9 & 4.6 \\
\hline Ryegrass & 12.2 & 18.7 & 23.1 & 3.7 \\
\hline S.E. & 0.21 & 0.27 & 0.59 & 0.12 \\
\hline \multicolumn{5}{|l|}{ Jun. 27, 1972: } \\
\hline Browntop & 13.2 & 16.2 & 18.7 & 4.1 \\
\hline Ryegrass & 10.8 & 14.2 & 21.7 & 4.3 \\
\hline S.E. & 0.06 & 0.33 & 0.12 & 0.10 \\
\hline
\end{tabular}

browntop sheep at this or any other time. This presumably accounted for the weight differences at this period although it is not clear whether this is a real species difference or simply a result that is confounded by different plant growth habits. Keogh (1973) showed that staggers could be avoided if sheep were prevented from grazing in the base of ryegrass-dominant pasture's at this time of the year. Certainly the higher yields in browntop pastures in the current experiment would have prevented these sheep from grazing into the base of the pasture, whereas the ryegrass sheep on shorter feed would have been forced to graze in this area and thus apparently ingest the as yet unknown causative agent in the staggers syndrome.

\section{CONCLUSXONS}

Under the oonditions of these experiments, the main time of the year when the feeding value of browntop was inferior to perennial ryegrass was in the late spring-early summer period. It is interesting that this decline still occurred even though the swards were closely and evenly grazed, and the results do not suggest that variadons in graaing management can maintain the feeding value of browntop swards over the summer, if O.M. digestibility of the species falls as low as $49 \%$ as it did in these experiments. However, although close grazing and full utilization of hill country pastures at this time of the year may aid the maintenance of the feeding value of other sward components, it does appear that a research effort to improve the feeding value of browntop during the summer could pay dividends. The improvement of the feeding value of the species at other periods of the year is probably more dependent on obtaining cultivars with a more even spread of dry matter production rather than feeding value per se. 


\section{ACKN OWLEDGEMENTS}

C. S. M. Armstrong, A. S. D. King and B. A. Baker for skilled assistance.

\section{REFERENCES}

Bailey, R. W., 1967: N.Z. JI agric. Res., 10: 15-32.

Black, J. S., 1967: 4th Rep. Hill Fmg Res. O rg.

Cowlishaw, S. J.; Alder, F. E., 1960: J. agric. Sci., Camb., 54: 257-65.

Henderson, J. L.; Edwards, R. S.; Hammerton, J. L., 1962: J. agric. Sci., Camb., 59: 199-206.

Keogh, R. G., 1973: N.Z. Il exp. Agric., 1: 55-7.

Levy, E. B., 1970: Grasslands of N ew Zealand. Government Printer, Wellington. $374 \mathrm{pp}$.

Rae, A. L.; Brougham, R. W.; Glenday, A. C.: Butler, G. W., 1963: J. agric. Sci., Camb., 61: 187-W.

Suckling, F. E. T., 1960: N.Z. Jl agric. Res., 3: 579-91.

Terry, R. A.; Tilley, J. M. A., 1964: J. Br. GrassId Soc., 19: 363-72. 